\title{
Mercury Speciation in Hair of Children in Three Communities of the Amazon, Brazil
}

\author{
Jamile Salim Marinho, ${ }^{1,2}$ Marcelo Oliveira Lima, ${ }^{1}$ \\ Elisabeth Conceição de Oliveira Santos, ${ }^{1}$ Iracina Maura de Jesus, ${ }^{1}$ \\ Maria da Conceição N. Pinheiro, ${ }^{2}$ Cláudio Nahum Alves, ${ }^{2}$ \\ and Regina Celi Sarkis Muller ${ }^{2}$ \\ ${ }^{1}$ Evandro Chagas Institute, 316 Km, 07 Road, Levilândia, 67030-000 Ananindeua, PA, Brazil \\ ${ }^{2}$ Federal University of Pará, 01 Augusto Corrêa Street, Guamá, 66075-110 Belém, PA, Brazil \\ Correspondence should be addressed to Jamile Salim Marinho; jmilemarinho@hotmail.com
}

Received 21 October 2013; Accepted 27 January 2014; Published 11 March 2014

Academic Editor: Erhan Unlu

Copyright (C) 2014 Jamile Salim Marinho et al. This is an open access article distributed under the Creative Commons Attribution License, which permits unrestricted use, distribution, and reproduction in any medium, provided the original work is properly cited.

Children from riverside communities located downstream of gold mining areas may be chronically exposed to relatively high levels of $\mathrm{MeHg}$ through the consumption of fish of this region. The objective of this study was to evaluate and compare levels of THg and $\mathrm{MeHg}$ in hair of children less than 12 years in communities near mines in the municipality of Itaituba and in communities far from prospecting areas in the city of Abaetetuba. The communities of Itaituba (Barreiras and São Luiz do Tapajós) had THg mean levels of $5.64 \pm 5.55 \mu \mathrm{g} \cdot \mathrm{g}^{-1}(0.43-27.82)$ and $11.41 \pm 7.16 \mu \mathrm{g} \cdot \mathrm{g}^{-1}(1.08-28.17)$, respectively, and an average count of MeHg relative to THg of $92.20 \%$ and $90.27 \%$, respectively. In the Maranhão community, the THg average concentrations results were $2.27 \pm 2.11 \mu \mathrm{g} \cdot \mathrm{g}^{-1}(0.13-$ 9.54) and the average values were $93.17 \%$ for $\mathrm{MeHg}$. Children of Itaituba had average levels of mercury above the limit established by the World Health Organization $\left(10 \mu \mathrm{g} \cdot \mathrm{g}^{-1}\right)$ and the strong correlation coefficient between the communities $(R=0.968$ and $P=0.0001)$ suggests the hair as an excellent biomarker of human exposure to organic mercury in riverside populations of the Tapajós, which has the intake of fish daily as main source of protein dietary.

\section{Introduction}

In the Amazon, there are records that the industrial and artisanal mining of gold and, possibly, other natural and anthropogenic sources, have increased the concentration of mercury $(\mathrm{Hg})$ in the environment, resulting, through the trophic chain, in process of bioaccumulation in fish consumed by riverside communities. Previous studies related elevated levels of $\mathrm{Hg}$ in fish consumption in these communities [1-5].

The mercury is toxic in its various physical and chemical forms, being identified as one of the most dangerous pollutants in the environment [6-8]. This toxicity is amplified in the organomercury forms, particularly methylmercury (MeHg), a substance of high volatility and easily absorbed across biological membranes, with records of efficient bioaccumulation and long-term attachment to the tissues $[9,10]$.
Previous studies indicate that the bioaccumulation of $\mathrm{Hg}$ is harmful to human being, with increments of risk in vulnerable groups such as that, for example, children can receive burden of $\mathrm{Hg}$ from mothers infected during pregnancy [11]. By the experimental studies, there are reports on the harmful effects of $\mathrm{Hg}$ to the development of human biological systems, with evidence of alterations on the cardiovascular, neurological, immune, and respiratory systems; effects that may persist for entire life $[12,13]$.

Children are more vulnerable to mercury exposure [14]. Therefore, children from riverside communities located downstream from gold mining areas, may be chronically exposed to relatively high levels of $\mathrm{MeHg}$ by fish consumption [15]. From previous studies, it is estimated that $\mathrm{MeHg}$ represents approximately $70-90 \%$ of the total mercury (THg) consumed by the fish [15-17]. Thus, in these communities, the environmental monitoring of $\mathrm{THg}$ and $\mathrm{MeHg}$ levels in hair 


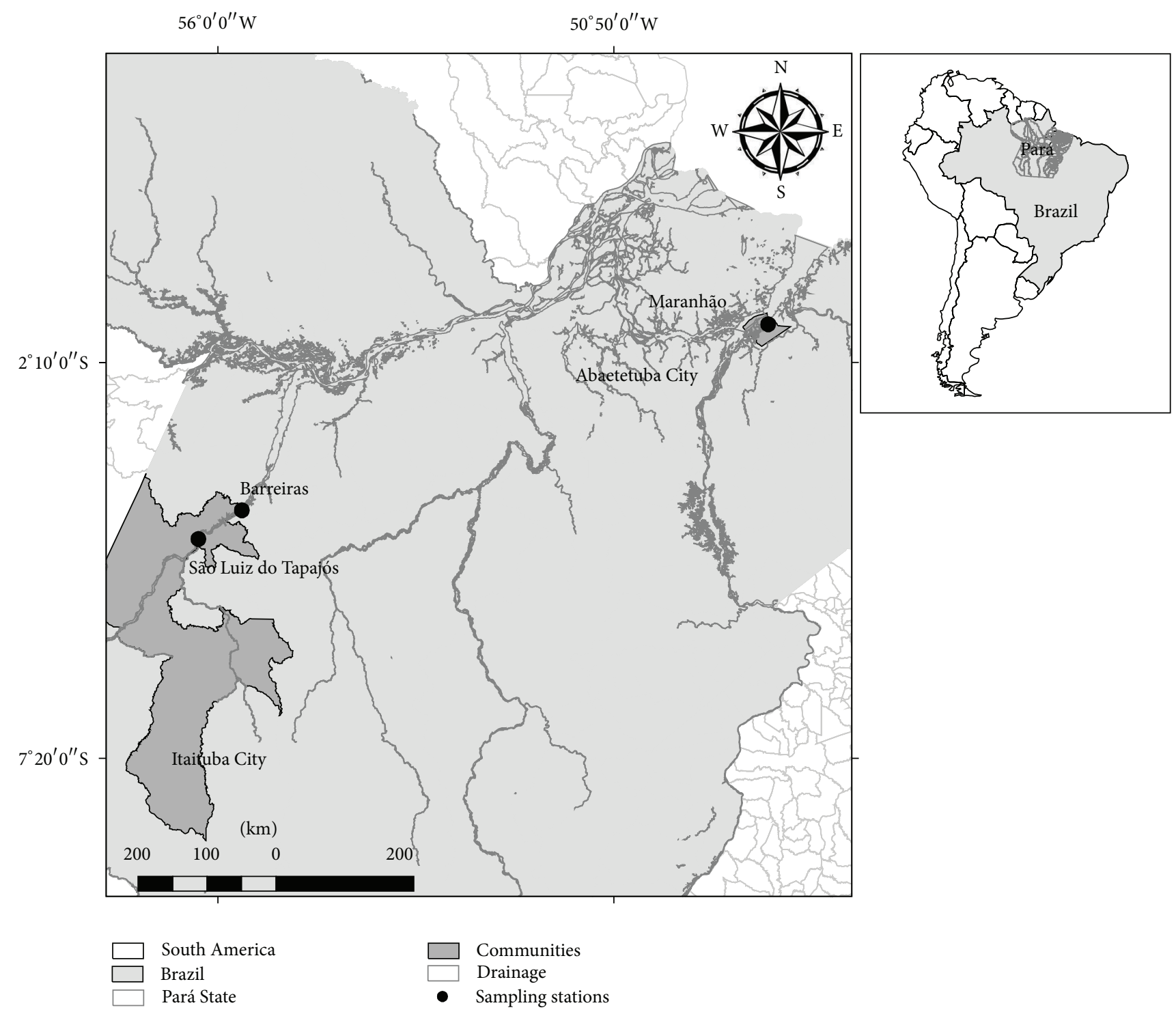

FIGURE 1: Study area encompassing the communities of Barreiras, São Luiz do Tapajós, and Maranhão.

associated with the epidemiological information represents important steps to ensure the quality of life of these populations.

The objective of this study was to perform a quantitative comparison of $\mathrm{THg}$ and $\mathrm{MeHg}$ levels in children younger than 12 years on populations in near and distant prospecting areas of the Amazon, associating these results with epidemiological data obtained through interviews.

\section{Material and Methods}

2.1. Study Area. For this study, children were selected in three Amazonian communities: São Luiz do Tapajós, Barreiras, and Maranhão (Figure 1). The localities of São Luiz do Tapajós (Lat (S): $4^{\circ} 28^{\prime} 11^{\prime \prime}$ and Long (W): $56^{\circ} 15^{\prime} 20^{\prime \prime}$ ) and Barreiras (Lat (S): $4^{\circ} 5^{\prime} 34^{\prime \prime}$ and Long (W): $55^{\circ} 41^{\prime} 11^{\prime \prime}$ ), with 460 and 740 people, respectively, are located on the banks of the Tapajós
River, near the town of Itaituba in southwestern Pará. In this region, considered as the $\mathrm{Hg}$ exposure, there are records of more than four decades of gold mining [18]. The Maranhão community (Lat (S): $1^{\circ} 39^{\prime} 56^{\prime \prime}$ and Long (W): $48^{\circ} 49^{\prime} 10^{\prime \prime}$ ), with approximately 500 inhabitants, is located on the banks of the Guajará of Beja, a tributary of the right bank of the Pará River, in the northeastern region of the State of Pará, an area where there are no records of exposure to $\mathrm{Hg}$.

2.2. Epidemiology. Individuals who reside in the communities selected for this study have similar lifestyles, highlighting the continuous intake of fish as the main protein source. However, these populations are differentiated based on the influences exerted by gold mining activities whose environmental exposure to $\mathrm{Hg}$ is higher in those communities located on the banks of the Tapajós River. 


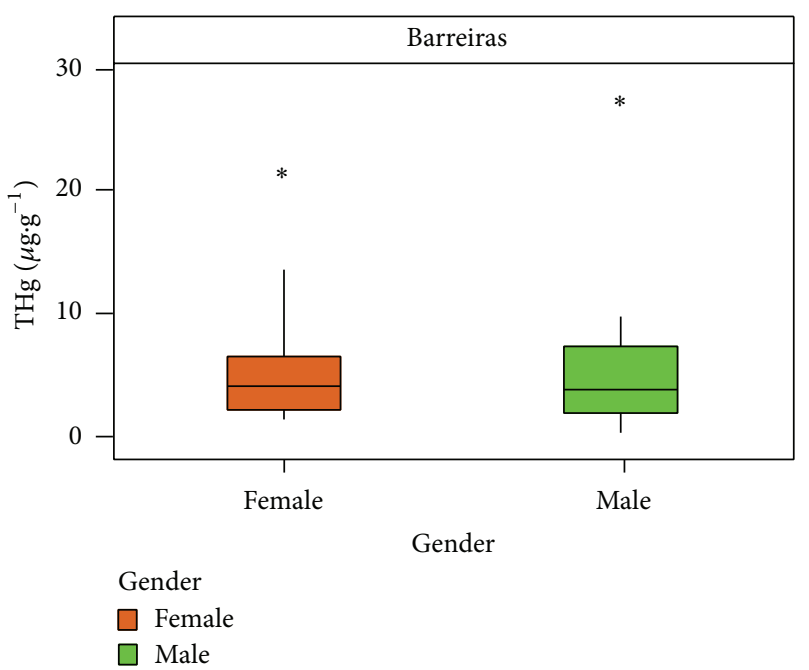

(a)

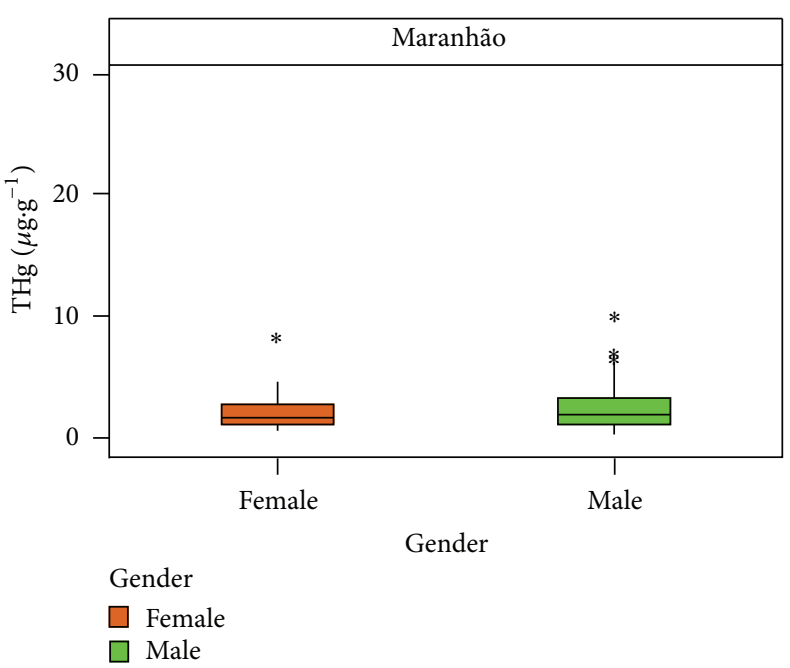

(b)

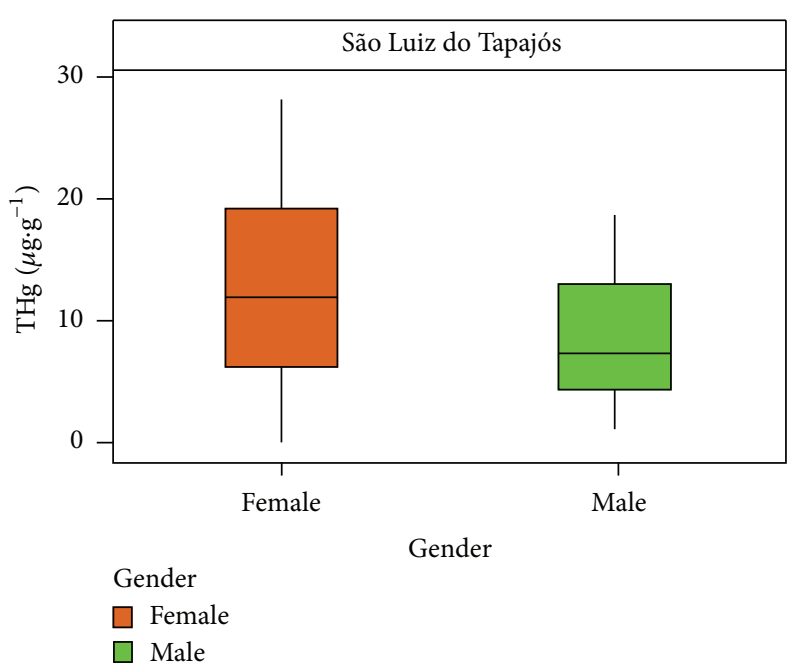

(c)

Figure 2: Box plot average levels of THg by gender.

The recruitment of individuals was performed by invitation in the communities. The research project was explained to the people responsible for these children, who gave permission by signing the Free and Clarified Consent Term (FCCT). Between 2007 and 2009, a total of 195 children aged 0-12 years old were selected to participate in this study. Of this group, 37 children are residents of the community of Barreiras, 40 are from São Luiz do Tapajós, and 118 are from the Maranhão community.

Epidemiological data, such as age, sex, and length of stay at the place, were obtained through interviews with parental or legal guardian monitoring. Approval for the study procedures was obtained by the Ethics Committee in Research of the Evandro Chagas Institute, by registration number 0013/2008, approved on 09/06/2009.

2.3. Sampling and Sample Management. The hair samples were collected from the head occipital area, approximately one (1) $\mathrm{cm}$ from the scalp of children with stainless steel dissecting scissors, and stored in paper envelopes properly identified. These samples were then sent to the Division of Mercury in the Laboratory of Toxicology, Section of Environment (SAMAM) of the Evandro Chagas Institute (ECI), located in the town of Ananindeua, State of Pará, Brazil. In the laboratory, the samples were washed with neutral detergent solution (Extran-Merck MA 0-alkaline) (diluted 100 times) to eliminate possible exogenous contamination, deionized water (Milli-Q) to remove sediments, and acetone (Merck) to enable water evaporation, reducing the humidification. After the washing step and subsequent drying, the samples were transferred to $20 \mathrm{~mL}$ amber vials and perforated with stainless steel dissecting scissors for greater homogenization [19].

2.4. Total Mercury ( $\mathrm{THg}$ ). In analysis of $\mathrm{THg}$ in hair, the methodology developed by [19] was applied that involves the steps of wet digestion, reduction with stannous chloride 


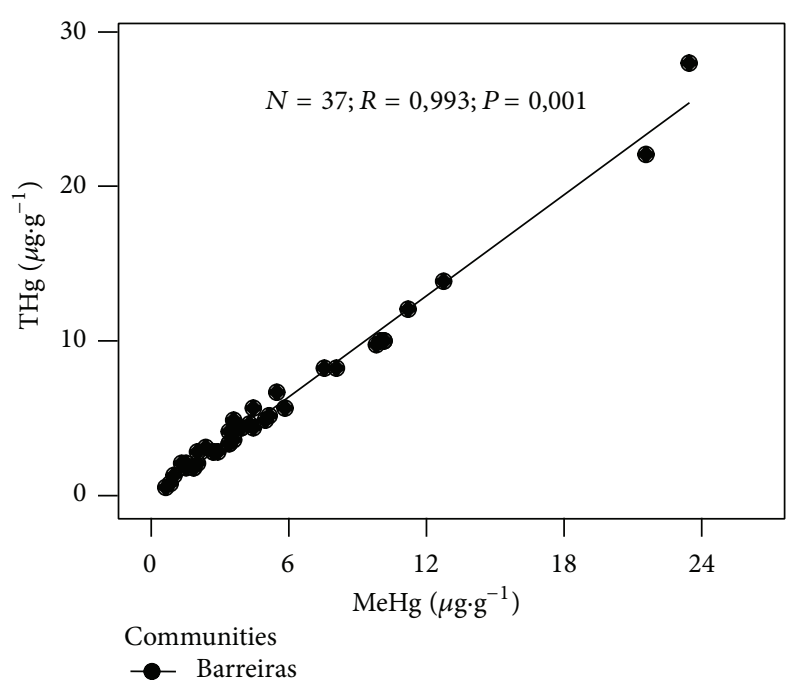

(a)

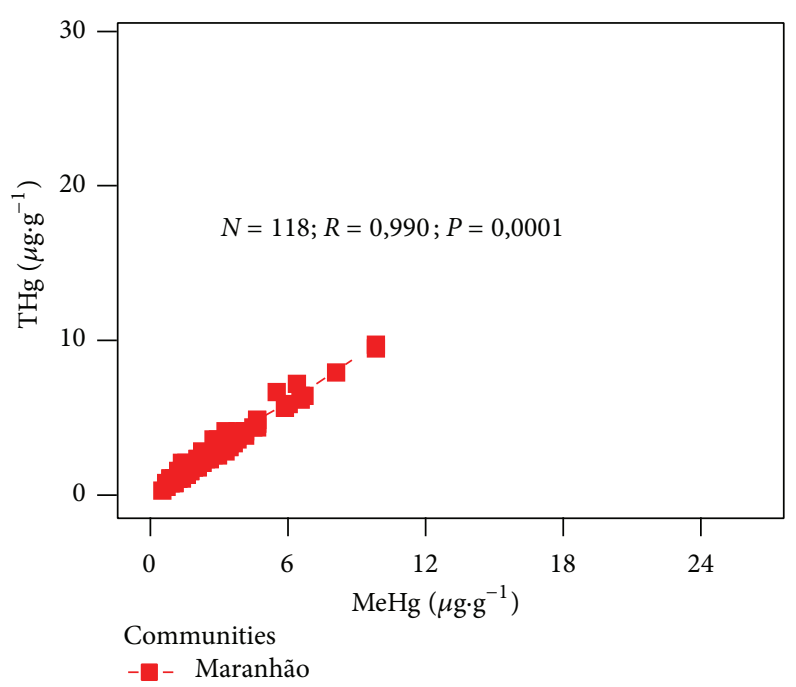

(b)

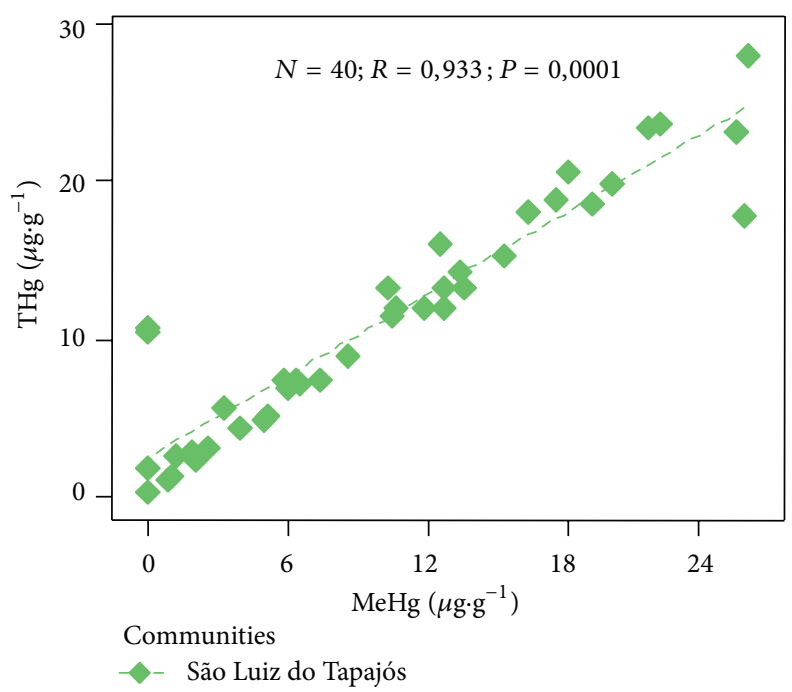

(c)

Figure 3: Correlation between levels of THg and MeHg in Barreiras, São Luiz do Tapajós, and Maranhão. Confidence interval is 95\%.

$\left(\mathrm{SnCl}_{2}\right)$, and quantification by cold vapor atomic absorption spectrometry (CVAAS). In this method, about $0.01 \mathrm{~g}$ of each sample was weighed in a $50 \mathrm{~mL}$ volumetric flask (Pyrex), and $1 \mathrm{~mL}$ of deionized water was added plus $2 \mathrm{~mL}$ of $\mathrm{HNO}_{3}+$ $\mathrm{HClO}_{4}(1: 1)$ and $5 \mathrm{~mL}$ of $\mathrm{H}_{2} \mathrm{SO}_{4}$ and heated for 30 minutes in a hot plate at a temperature of $230^{\circ} \mathrm{C}$. After cooling, the solution was measured with deionized water obtained by the water purification system (Millipore, Academic Milli-Q model) to a final volume of $50 \mathrm{~mL}$.

After digestion, $5 \mathrm{~mL}$ of sample was added in the reactor vial of the $\mathrm{Hg}$ analyzer, Automatic Mercury Analyzer Hg201 (Sanso Company), with the addition of $1 \mathrm{~mL}$ of stannous chloride $\left(\mathrm{SnCl}_{2}-10 \%\right)$ to reduce $\mathrm{Hg}^{2+}$ to $\mathrm{Hg}^{0}$. Then, the $\mathrm{Hg}$ vapor generated is conducted into a flask containing $\mathrm{NaOH}$ at $5 \mathrm{~N}$, that neutralizes the acid vapors, and a flask containing an ice bath, which condenses water vapor. Thereupon, the $\mathrm{Hg}$ vapors are transported to the photoabsorption cell to measure absorbance of $253.7 \mathrm{~mm}$. The reading is performed within one minute and can be measured until $0.1 \mathrm{ng}$ of $\mathrm{Hg}$ with high accuracy [19].

In the analysis of THg, calibration curves were used: 0,20 , 50 , and $100 \mathrm{ng}$ of $\mathrm{Hg}$ prepared starting from standard solution of $0.1 \mathrm{ppm} \mathrm{MeHg-cysteine.}$

2.5. Methylmercury $(\mathrm{MeHg})$. In the analysis of $\mathrm{MeHg}$ in hair, the simplified method proposed by Akagi [19] was applied, which involves leaching with hydrochloric acid, extraction with toluene, and quantification by gas chromatography with electron capture detector (GC-ECD). In this method, approximately $0.02 \mathrm{~g}$ of each sample was weighed and transferred to a round bottom centrifuge tube of $10 \mathrm{~mL}$. Subsequently, 2 drops of ethanol and a small amount of cotton to moisten and cover the sample were added, respectively. For leaching from $\mathrm{MeHg}$, samples were immersed in $3 \mathrm{~mL}$ of $\mathrm{HCl}$ at $2 \mathrm{~N}$ 


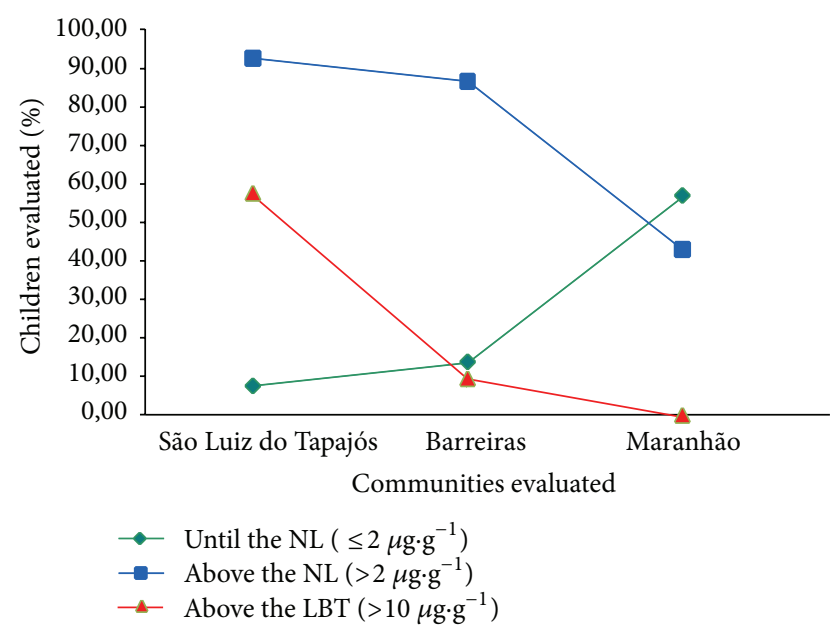

FIgURE 4: Percentage number of children with levels of THg until normality limit (NL), above the normality limit (NL) and above limits of biological tolerance (LBT).

and heated at $100^{\circ} \mathrm{C}$ for 5 minutes. After cooling, the samples were centrifuged at $1200 \mathrm{rpm}$ for 3 minutes. Then, $1 \mathrm{~mL}$ of the supernatant was transferred to a conical tube centrifuge of $10 \mathrm{~mL}$ and $2 \mathrm{~mL}$ of toluene was added with stirring for 3 minutes to extract the $\mathrm{MeHg}$ in the phase of $\mathrm{HCl}$ to the phase of toluene. After digestion, $2 \mu \mathrm{L}$ of sample was injected into the GC-ECD (Yanaco), series G-6800. Glass column of $3.0 \mathrm{~mm} \times 0.75 \mathrm{~m}$ was used and packed with $10 \% \mathrm{KOCl}-\mathrm{Hg}$ on Chromosorb W (AW-DMCS, 60-80, Ltd., Kyoto, Japan).

2.6. Quality Control. As quality criteria for the analysis of $\mathrm{THg}$ and $\mathrm{MeHg}$, Certified Reference Material (CRM) IAEA 86 and IAEA 085 were used.

2.7. Statistics. For statistical analyses, the data were submitted to the program Microsoft Excel 2007 and MINITAB 14 software [20]. For results with statistical significance, $P \leq$ 0.05 was used. In correlation analyses, $R=1$ for perfect correlation; $R$ next to \pm 0.9 , for strong correlation; $R$ next to \pm 0.1 , for weak correlation; and $R=0$, for zero correlation were considered [21].

\section{Results and Discussion}

3.1. Quality Control. The average results of the analysis of $\mathrm{THg}$ and $\mathrm{MeHg}$ in the samples from CRM and their reference values are shown in Table 1 . The great analytical recovery for $\mathrm{THg}$ (99.21\%) and $\mathrm{MeHg}$ (94.35\%) showed that the methodology was effective.

3.2. Epidemiology. From the epidemiological information, the children were grouped into different age groups according to the stages of life [18]: (A) breast-feeding (0-1 years), (B) prekindergarten or preschool (2-6 years), and (C) childhood or school (7-12 years). In the three communities, despite the different sample sizes, a similar pattern of distribution of individuals between stages of life evaluated was observed; in other words, in the research, there was the prevalence of children at school phase. Regarding gender, in the Barreiras, the male children (54\%) are of larger numbers than the females (46\%). On the other hand, in São Luiz do Tapajós, this predominance was higher in female children (60\%) than male ones (40\%). This inversion was also observed in Maranhão community, in which the number of female children (52.5\%) was also higher than male children (47.5\%).

Children from Barreiras and São Luiz do Tapajós were also divided into another two groups, in relation to paternal occupation, in order to analyze the importance of familial influences on exposure to $\mathrm{Hg}$ : $(\mathrm{y})$ children whose fathers were fisherman and $(\mathrm{x})$ children whose fathers were not fisherman. In Barreiras, the children (x) are of higher amounts $(60 \%)$ than the children (y) (40\%). In contrast, in São Luiz do Tapajós, this profile was higher in children (y) (55\%) than in (x) (45\%). As regards the duration of breast-feeding, in Barreiras, the average time was about 6 months, while, in São Luiz do Tapajós, this mean increased to 10 months.

3.3. Results of HG. The average results of $\mathrm{THg}$ and $\mathrm{MeHg}$, standard deviation, and the mean percentage of $\mathrm{MeHg}$ in children of the communities investigated are presented in Table 2. The highest average levels of THg $\left(11.41 \mu \mathrm{g} \cdot \mathrm{g}^{-1}\right)$ and $\mathrm{MeHg}\left(10.30 \mu \mathrm{g} \cdot \mathrm{g}^{-1}\right)$ in hair of children were found in the community of São Luiz do Tapajós. These values are twice the average of THg $\left(5.64 \mu \mathrm{g} \cdot \mathrm{g}^{-1}\right)$ and $\mathrm{MeHg}\left(5.20 \mu \mathrm{g} \cdot \mathrm{g}^{-1}\right)$ found in Barreiras and four times higher than the results of THg $\left(2.27 \mu \mathrm{g} \cdot \mathrm{g}^{-1}\right)$ and $\mathrm{MeHg}\left(2.11 \mu \mathrm{g} \cdot \mathrm{g}^{-1}\right)$ in the Maranhão community. These results confirm previous comparative studies with riverside populations of areas exposed and not exposed to $\mathrm{Hg}$, which detect higher levels of $\mathrm{THg}$ in the community of São Luiz do Tapajós [15, 18, 22, 23], possibly because of higher proximity of the community with the gold mining area of the Tapajos River Basin [5].

Regarding gender, in the communities of Barreiras and São Luiz do Tapajós, the female children had average levels of THg higher than $4.27 \mu \mathrm{g} \cdot \mathrm{g}^{-1}(2.29-4.60)$ and $5.12 \mu \mathrm{g} \cdot \mathrm{g}^{-1}$ (6.12-19.41), relatively higher than the levels found in male children, which values were $4.1 \mu \mathrm{g} \cdot \mathrm{g}^{-1}(2.12-7.61)$ and $7.73 \mu \mathrm{g} \cdot \mathrm{g}^{-1}$ (4.3-13.2), respectively. In the Maranhão community, the THg highest mean levels were found in males, $1.78 \mu \mathrm{g} \cdot \mathrm{g}^{-1}(1.04-2.13)$, compared to THg levels found in females, $1.50 \mu \mathrm{g} \cdot \mathrm{g}^{-1}$ (1.01-2.61). THg mean levels by gender are shown in Figure 2. In contrast, studies have shown higher levels of mercury in male children from the communities of Barreiras and São Luiz dos Tapajós [18]. Also, the occurrence of outliers in the community of Barreiras is noteworthy, where there was registration of two children; both are sons of fisherman father, with levels of $21.96 \mu \mathrm{g} \cdot \mathrm{g}^{-1}$ (female) and $27.82 \mu \mathrm{g} \cdot \mathrm{g}^{-1}$ (male). In this case, the female child deserves more detailed attention, whose epidemiological surveys show delays in the development of the motor system.

In the analysis of correlation, a strong correlation between the levels of $\mathrm{THg}$ and $\mathrm{MeHg}$ in hair of children of Barreiras $(R=0.99$ and $P=0.0001)$, São Luiz do Tapajós $(R=$ 0.93 and $P=0.0001)$, and Maranhão $(R=0.99$ and 


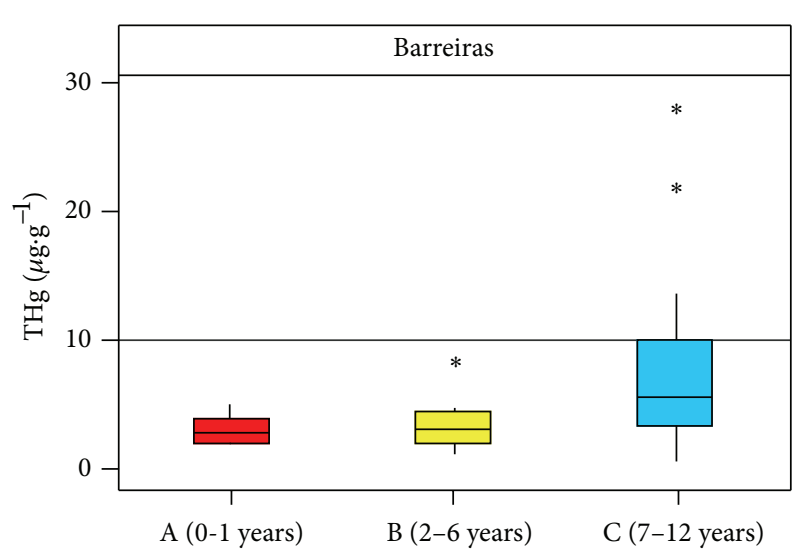

Age groups

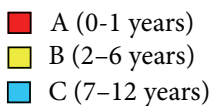

$\square$ A ( $0-1$ years $)$
$\square$ B ( $2-6$ years $)$

$\square$ C (7-12 years)

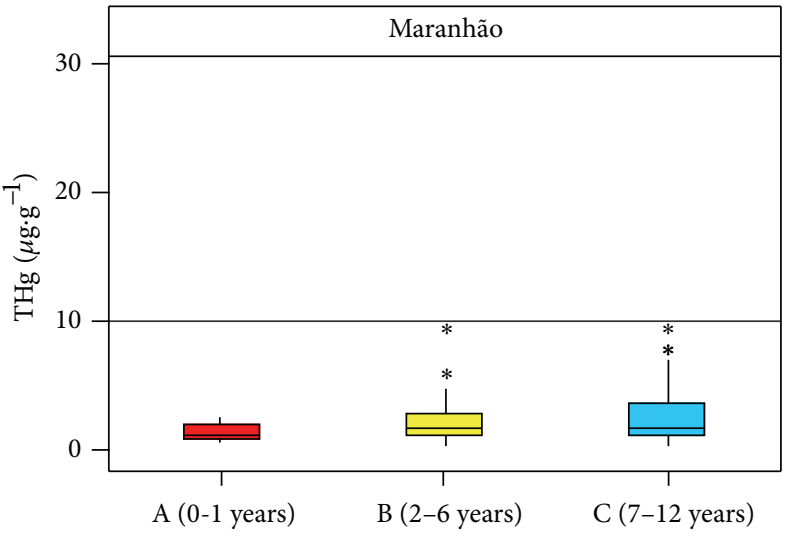

Age groups

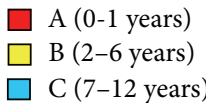

(a)

(b)

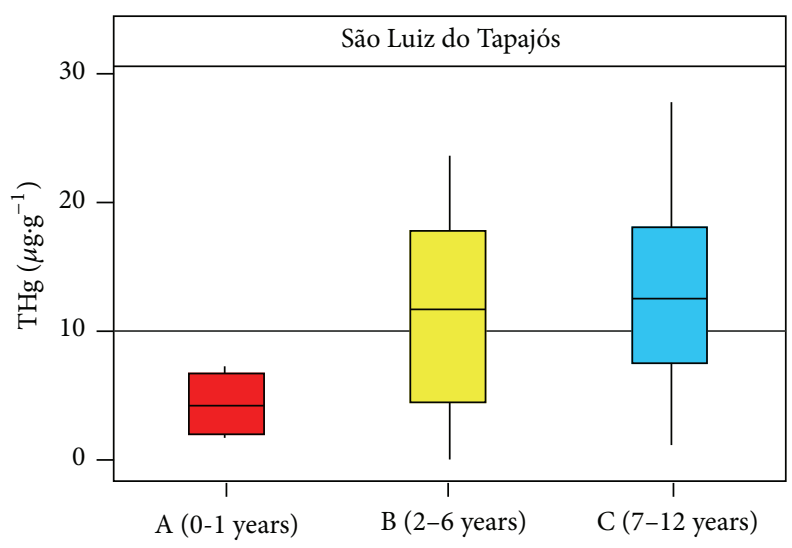

Age groups

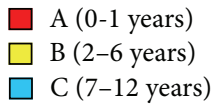

(c)

FIGURE 5: Box plot average levels of THg in hair of children by age groups. The horizontal line represents the limits of biological tolerance (LBT) by WHO $\left(10 \mu \mathrm{g} \cdot \mathrm{g}^{-1}\right)$.

TABLE 1: Analytical recovery of THg and MeHg in Certificate Reference Material (CRM).

\begin{tabular}{lccccc}
\hline CRM & Analyte & $N^{*}$ & Mean \pm SD $\left(\mu{\left.\mathrm{g} \cdot \mathrm{g}^{-1}\right)}^{\text {Reference values }\left(\mu \mathrm{g} \cdot \mathrm{g}^{-1}\right)}\right.$ & 0.573 & Recovery $(\%)$ \\
\hline IAEA 086 & $\mathrm{THg}$ & 38 & $0.568 \pm 0.084$ & 20.73 & 99.21 \\
IAEA 085 & $\mathrm{MeHg}$ & 5 & $23.2 \pm 5.35$ & 94.35 \\
\hline
\end{tabular}

${ }^{*}$ Number of samples.

TABLE 2: The average results of $\mathrm{THg}$ and $\mathrm{MeHg}$ and the mean percentage of $\mathrm{MeHg}$.

\begin{tabular}{|c|c|c|c|c|c|c|}
\hline \multirow{2}{*}{ Communities } & \multirow{2}{*}{$N^{*}$} & \multicolumn{2}{|c|}{$\operatorname{HgT}\left(\mu g \cdot g^{-1}\right)$} & \multicolumn{2}{|c|}{$\operatorname{MeHg}\left(\mu \mathrm{g} \cdot \mathrm{g}^{-1}\right)$} & \multirow{2}{*}{$\% \mathrm{MeHg}^{* *}$} \\
\hline & & Mean \pm SD & Range & Mean \pm SD & Range & \\
\hline Maranhão & 139 & $2.27 \pm 1.84$ & $0.13-9.54$ & $2.11 \pm 1.82$ & $0.12-9.54$ & 93.17 \\
\hline S.L. do Tapajós & 40 & $11.41 \pm 7.16$ & $1.08-28.17$ & $10.30 \pm 7.67$ & $0.96-25.74$ & 90.27 \\
\hline Barreiras & 37 & $5.64 \pm 5.55$ & $0.43-27.82$ & $5.20 \pm 5.06$ & $0.43-23.20$ & 92.20 \\
\hline
\end{tabular}

${ }^{*}$ Number of samples

** Mean percentage of methylmercury $(\mathrm{MeHg} / \mathrm{THg} \times 100)$. 


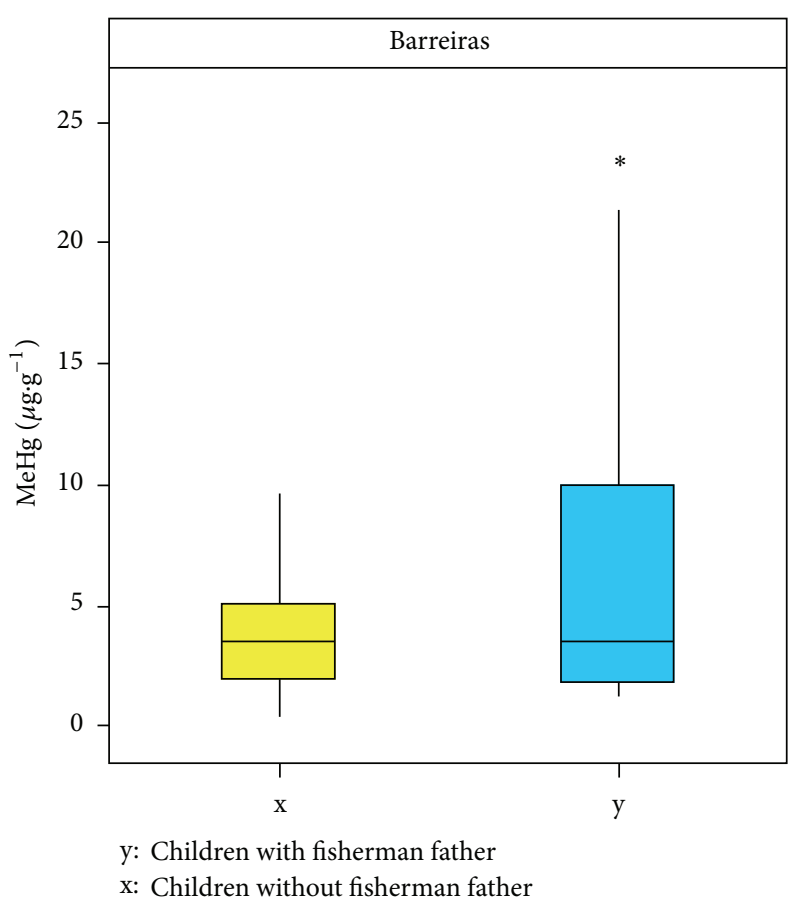

(a)

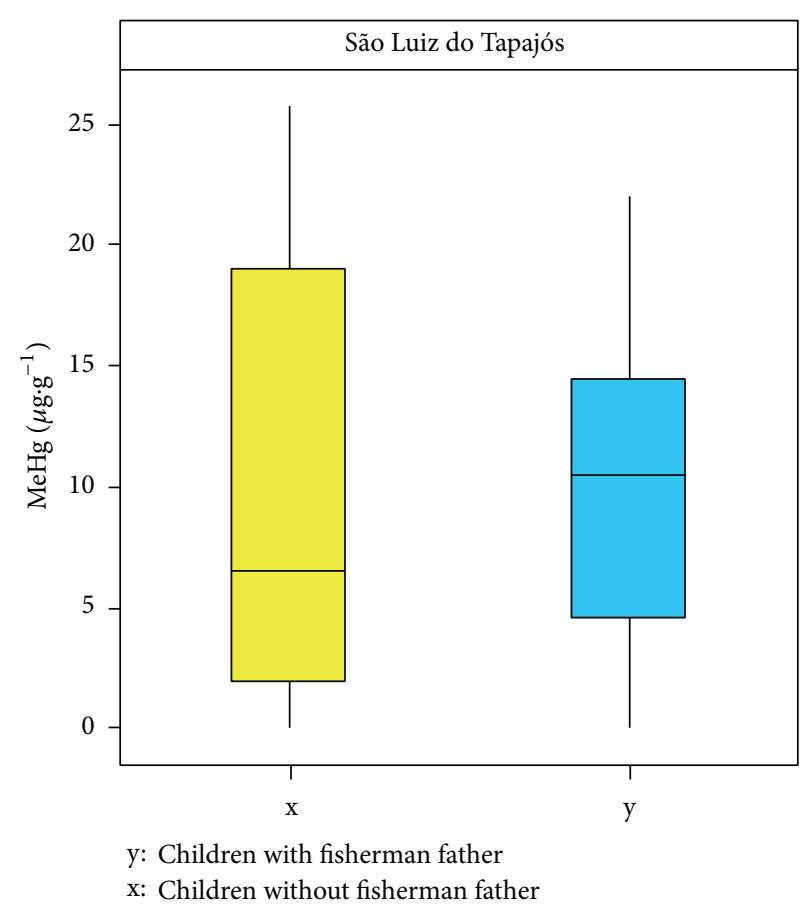

(b)

Figure 6: Box plot levels of MeHg in Barreiras and São Luiz do Tapajós versus paternal occupation.

$P=0.0001)$, Figure 3 , was observed. The strong correlation coefficient found between $\mathrm{THg}$ and $\mathrm{MeHg}$ in hair and the high percentage of $\mathrm{MeHg}(>90 \%)$ suggest that the hair can be considered as an excellent biomarker of $\mathrm{MeHg}$ exposure in children, especially in communities where there is the record of high fish consumption by these individuals at all stages of life $[1,24,25]$. Consequently, the measurement of $\mathrm{Hg}$ levels in hair is considered the main indicator of exposure in populations exposed to $\mathrm{MeHg}$ and is used to define international guidelines [26].

In Barreiras, despite the fact that the found $\mathrm{THg}$ average levels were below the limits of biological tolerance (LBT = $10 \mu \mathrm{g} \cdot \mathrm{g}^{-1}$ ) established by World Health Organization (WHO), about $10 \%$ of children of all age groups had THg levels above this limit and $86.48 \%$ of children had shown $\mathrm{THg}$ levels above the normality limit $\left(\mathrm{NL}=2 \mu \mathrm{g} \cdot \mathrm{g}^{-1}\right)$ proposed by WHO, reaching a maximum concentration of $27.82 \mu \mathrm{g} \cdot \mathrm{g}^{-1}$, THg level almost three times higher than LBT. In São Luiz do Tapajós, $92.5 \%$ of children had $\mathrm{THg}$ levels above the $\mathrm{NL}$ and $57.5 \%$ reached concentrations above LBT, reaching the highest concentration of $28.17 \mu \mathrm{g} \cdot \mathrm{g}^{-1}$. In the Maranhão community, despite being a candidate region to control area, about $43 \%$ of children had THg levels above the NL $\left(2 \mu \mathrm{g} \cdot \mathrm{g}^{-1}\right)$, but there were no children with levels above the LBT of $10 \mu \mathrm{g} \cdot \mathrm{g}^{-1}$ (Figure 4). These results are strong indication that, even today, the children of the communities located on the banks of the Tapajós River are more exposed to $\mathrm{MeHg}$ mainly than those of the community of São Luiz do Tapajós.

The average of $\mathrm{THg}$ concentrations per age groups is provided in box plot in Figure 5. In Barreiras and São Luiz do Tapajós, the highest levels of THg were found in children of the C group (5.5 and $12.5 \mu \mathrm{g} \cdot \mathrm{g}^{-1}$, resp.); these results may be related to the time of exposure of children of this group, that is larger compared with A and B groups. In the Maranhão community, the highest levels of THg were found in children of the B group $\left(1.7 \mu \mathrm{g} \cdot \mathrm{g}^{-1}\right)$. The communities of Barreiras, São Luiz do Tapajós, and Maranhão showed different levels of mercury in different age groups, confirming previous reports that different mercury levels can be found in different age groups $[18,23,27]$.

Regarding the time (in months) of breast-feeding, there was no significant correlation with $\mathrm{MeHg}$ in the communities of Barreiras $(R=-0.01, P=0.971)$ and São Luiz dos Tapajós $(R=-0.05, P=0.763)$. In the Maranhão community, information was not collected on duration of breast-feeding of children. This can be explained by the fact that inorganic mercury is more easily transmitted from blood to milk than the methylmercury $[11,28-30]$. The preferential inorganic $\mathrm{Hg}$ distribution to breast milk is consistent with the association between $\mathrm{Hg}$ in plasma, since $\mathrm{MeHg}$ is preferably partitioned to erythrocytes [31]. Studies also showed that the mercury of the breastfed children's hair was not significantly correlated with levels of mercury in breast milk [32].

In the community of Barreiras, there was a significant correlation ( $R=0.67, P=0.0001)$ between the levels of $\mathrm{MeHg}$ found with the current weight of children. The consumption of food, including fish, is directly proportional to the weight of the children. Then, this may result in elevated caloric and protein intake, which can increase the levels of childhood exposure to mercury [11]. Furthermore, 
children may have not yet fully developed the metabolic excretion pathways, resulting in inefficiency of detoxification and physiological elimination of contaminants [11]. This result was not found for the community of São Luiz do Tapajós $(R=-0.02, P=0.892)$.

In relation to family life, children were divided into two groups ( $\mathrm{x}$ and $\mathrm{y}$ ), namely, $\mathrm{y}$ represented children with fisherman father, and $\mathrm{x}$ was related to children whose fathers were not fisherman. The children of the (y) group had higher average levels of $\mathrm{MeHg}$ in relation to the children of (x) group in both communities (Figure 6). In the community of Barreiras, the children of (y) group showed average levels of $\mathrm{MeHg}$ of $7.33 \mu \mathrm{g} \cdot \mathrm{g}^{-1}$ (3.38-11:27), while, in the (x) group ones, it was $3.75 \mu \mathrm{g} \cdot \mathrm{g}^{-1}(2.68-4.81)$. In São Luiz do Tapajós, although the (y) group had showed higher average levels of $\mathrm{MeHg}, 10.54 \mu \mathrm{g} \cdot \mathrm{g}^{-1}$ (4.88-10.67), compared with the values of (x) group, $6.44 \mu \mathrm{g} \cdot \mathrm{g}^{-1}(1.73-16.11)$, this group had children with mercury levels above the ones established by WHO $\left(10 \mu \mathrm{g} \cdot \mathrm{g}^{-1}\right)$. Knowing that the aquatic biota is the main mercury transfer form from contaminated environment to humans in riverside communities $[4,9,18,27,33]$, this result is justified, since it has been found, through epidemiological questionnaire, that $76.62 \%$ of the children of this region have fish as main source of dietary protein.

In studies in humans in the Tapajós River Basin, possible reduction of $\mathrm{Hg}$ levels in recent years [34] has been reported. In 2001, the $\mathrm{Hg}$ levels obtained average of $20 \mu \mathrm{g} \cdot \mathrm{g}^{-1}[1,25,35$, 36]. However, further studies in the same populations showed lower levels, approximately $15 \mu \mathrm{g} \cdot \mathrm{g}^{-1}[5,8,13,18,22,37]$, but these levels are still above LBT $\left(10 \mu \mathrm{g} \cdot \mathrm{g}^{-1}\right)$ established by WHO. In children, this tendency is also observed. In a study in the community of São Luiz do Tapajós in 1999, the THg levels found in children were $15 \mu \mathrm{g} \cdot \mathrm{g}^{-1}$ [36], and, in 2007, such levels were $13.39 \mu \mathrm{g} \cdot \mathrm{g}^{-1}$ [18]. Our results confirm a possible reduction of $\mathrm{Hg}$ levels in children from the communities of São Luiz do Tapajós and Barreiras (11.41 and 5.64 $\mu \mathrm{g} \cdot \mathrm{g}^{-1}$, resp.). In São Luiz do Tapajós, despite having average levels of THg lower than those found in previous studies, this average is still above LBT.

\section{Conclusions}

Mercury exposure represents a growing health problem, mainly for riverside children, who are particularly susceptible to the effects of mercury exposure during specific periods of rapid growth and development [11]. The riverside communities of the Tapajós Valley are exposed to mercury for decades and despite the fact that recent studies show a trend of decrease of mercury levels in these populations [34], in this research these concentrations in the children hair still meet the above biological tolerance limit established by WHO $\left(10 \mu \mathrm{g} \cdot \mathrm{g}^{-1}\right)$.

The strong correlation coefficient $(R=0.96$ and $P=$ $0.0001)$ confirms hair as an excellent biomarker of human exposure to the organic mercury in riverside populations of the Tapajós, which has the consumption of fish daily as main feed protein source.
The results showed that the decrease in craft production in the region begins to be reflected in decreased levels of mercury in the children of the region. This decrease, although still small in scale, represents a decrease of environmental exposure to mercury in the Amazon.

Children of the Tapajós had higher average levels of mercury compared to children of the community Maranhão (area without the influence of mining). These data alerts us about the importance of comparative studies in order to obtain accurate assessments and help to establish reference levels of mercury in exposed and not exposed children in the Amazon. It also becomes relevant an clinical, epidemiological and laboratory study more refined in children from Barreiras community, who presented high levels of $\mathrm{Hg}$ and recorded problems in the development of the motor system.

\section{Conflict of Interests}

The authors declare that there is no conflict of interests regarding the publication of this paper.

\section{Acknowledgments}

The authors thank the Evandro Chagas Institute and the Federal University of Pará for supporting the searches.

\section{References}

[1] M. Harada, J. Nakanishi, E. Yasoda et al., "Mercury pollution in the Tapajos River basin, Amazon mercury level of head hair and health effects," Environment International, vol. 27, no. 4, pp. 285-290, 2001.

[2] R. C. Marques, J. G. Dórea, W. R. Bastos, M. de Freitas Rebelo, M. de Freitas Fonseca, and O. Malm, "Maternal mercury exposure and neuro-motor development in breastfed infants from Porto Velho (Amazon), Brazil," International Journal of Hygiene and Environmental Health, vol. 210, no. 1, pp. 51-60, 2007.

[3] E. C. De Oliveira Santos, I. M. De Jesus, E. Da Silva Brabo et al., "Mercury exposures in riverside amazon communities in Para, Brazil," Environmental Research, vol. 84, no. 2, pp. 100-107, 2000.

[4] M. Gochfeld, "Cases of mercury exposure, bioavailability, and absorption," Ecotoxicology and Environmental Safety, vol. 56, no. 1, pp. 174-179, 2003.

[5] M. C. N. Pinheiro, B. M. Macchi, J. L. F. Vieira et al., "Mercury exposure and antioxidant defenses in women: a comparative study in the Amazon," Environmental Research, vol. 107, no. 1, pp. 53-59, 2008.

[6] D. Mergler, H. A. Anderson, L. H. M. Chan et al., "Methylmercury exposure and health effects in humans: a worldwide concern," Ambio, vol. 36, no. 1, pp. 3-11, 2007.

[7] P. Holmes, K. A. F. James, and L. S. Levy, "Is low-level environmental mercury exposure of concern to human health?" Science of the Total Environment, vol. 408, no. 2, pp. 171-182, 2009.

[8] D. Grotto, J. Valentini, M. Fillion et al., "Mercury exposure and oxidative stress in communities of the Brazilian Amazon," Science of the Total Environment, vol. 408, no. 4, pp. 806-811, 2010. 
[9] M. E. Crespo-López, A. M. Herculano, T. C. Corvelo, and J. L. Do Nascimento, "Mercury and neurotoxicity," Revista de Neurologia, vol. 40, no. 7, pp. 441-447, 2005.

[10] T. W. Clarkson and L. Magos, "The toxicology of mercury and its chemical compounds," Critical Reviews in Toxicology, vol.36, no. 8, pp. 609-662, 2006.

[11] WHO, Children's Exposure to Mercury Compounds, World Health organization, Geneva, Switzerland, 2010.

[12] "JECFA (United Nations Food and Agriculture Organization and World Health Organization Joint Expert Committee on Food Additives)," 2007, http://whqlibdoc.who.int/publications/ 2007/9789241660587_eng.pdf.

[13] M. Fillion, D. Mergler, C. J. Sousa Passos, F. Larribe, M. Lemire, and J. R. D. Guimarães, "A preliminary study of mercury exposure and blood pressure in the Brazilian Amazon," Environmental Health: A Global Access Science Source, vol. 5, article 29, 2006.

[14] US EPA, A Decade of Children's Environmental Health Research, Environmental Protection Agency, Washington, DC, USA, 2007, http://www.epa.gov/ncer/publications/research results_synthesis/ceh_report_508.pdf.

[15] M. C. N. Pinheiro, M. Harada, E. Yasoda et al., "Toxicological and epidemiological data on human exposure to mercury in the Tapajos River basin: 1994-1998," Environmental Science, vol. 10, no. 2, pp. 99-105, 2003.

[16] M. D. C. N. Pinheiro, J. Nakanishi, T. Oikawa et al., "Methylmercury human exposure in riverine villages of Tapajos basin, Para State, Brazil," Revista da Sociedade Brasileira de Medicina Tropical, vol. 33, no. 3, pp. 265-269, 2000.

[17] A. C. Barbosa, W. Jardim, J. G. Dórea, B. Fosberg, and J. Souza, "Hair mercury speciation as a function of gender, age, and body mass index in inhabitants of the negro river basin, amazon, brazil," Archives of Environmental Contamination and Toxicology, vol. 40, no. 3, pp. 439-444, 2001.

[18] M. C. N. Pinheiro, M. E. Crespo-López, J. L. F. Vieira et al., "Mercury pollution and childhood in Amazon riverside villages," Environment International, vol. 33, no. 1, pp. 56-61, 2007.

[19] H. Akagi, Mercury Analysis Manual, Ministry of the Environmental, Tokyo, Japan, 2004.

[20] MINITAB Statistical Software, Release 14 for Windows, State College, Pa, US, 2003.

[21] S. F. Costa, Introdução ilustrada á estatística, harbra, São Paulo, Brazil, 3rd edition, 1998.

[22] M. C. N. Pinheiro, R. C. S. Müller, J. E. Sarkis et al., "Mercury and selenium concentrations in hair samples of women in fertile age from Amazon riverside communities," Science of the Total Environment, vol. 349, no. 1-3, pp. 284-288, 2005.

[23] M. C. N. Pinheiro, T. Oikawa, J. L. F. Vieira et al., "Comparative study of human exposure to mercury in riverside communities in the Amazon region," Brazilian Journal of Medical and Biological Research, vol. 39, no. 3, pp. 411-414, 2006.

[24] M. Lemire, D. Mergler, M. Fillion et al., "Elevated blood selenium levels in the Brazilian Amazon," Science of the Total Environment, vol. 366, no. 1, pp. 101-111, 2006.

[25] H. Akagi, O. Malm, F. J. P. Branches et al., "Human exposure to mercury due to goldmining in the Tapajos River basin, Amazon, Brazil: speciation of mercury in human hair, blood and urine," Water, Air, and Soil Pollution, vol. 80, no. 1-4, pp. 85-94, 1995.

[26] US EPA, Methylmercury (MeHg) CASRN 22967-92-6. U.S. Environmental Protection Agency, Integrated Risk Information System, 1987.
[27] A. L. De Sá, A. M. Herculano, M. C. Pinheiro, L. C. L. Silveira, J. L. M. Do nascimento, and M. E. Crespo-López, "Human exposure to mercury in the west region of Pará State," Revista Paraense de Medicina, vol. 20, no. 1, pp. 19-25, 2006.

[28] M. Yoshida, C. Watanabe, H. Satoh, T. Kishimoto, and Y. Yamamura, "Milk transfer and tissue uptake of mercury in suckling offspring after exposure of lactating maternal guinea pigs to inorganic or methylmercury," Archives of Toxicology, vol. 68, no. 3, pp. 174-178, 1994.

[29] A. Oskarsson, A. Schütz, S. Skerfving, I. P. Hallén, B. Ohlin, and B. J. Lagerkvist, "Total and inorganic mercury in breast milk and blood in relation to fish consumption and amalgam fillings in lactating women," Archives of Environmental Health, vol. 51, no. 3, pp. 234-241, 1996.

[30] M. Sakamoto, M. Kubota, S.-I. Matsumoto, A. Nakano, and H. Akagi, "Declining risk of methylmercury exposure to infants during lactation," Environmental Research, vol. 90, no. 3, pp. 185-189, 2002.

[31] S. Skerfving, "Mercury in women exposed to methylmercury through fish consumption, and in their newborn babies and breast milk," Bulletin of Environmental Contamination and Toxicology, vol. 41, no. 4, pp. 475-482, 1988.

[32] A. C. Barbosa and J. G. Dórea, "Indices of mercury contamination during breast feeding in the Amazon Basin," Environmental Toxicology and Pharmacology, vol. 6, no. 2, pp. 71-79, 1998.

[33] M. E. Crespo-lópez, G. L. Macêdo, S. I. D. Pereira, G. P. F. Arrifano, D. L. W. Picanço-diniz, J. L. M. Do Nascimento et al., "Mercury and human genotoxicity: critical considerations and possible molecular mechanisms," Pharmacological Research, vol. 60, pp. 212-220, 2009.

[34] J. J. B. Nevado, R. C. Rodríguez Martín-Doimeadios, F. J. Guzmán Bernardo et al., "Mercury in the Tapajós River basin, Brazilian Amazon: a review," Environment International, vol. 36, no. 6, pp. 593-608, 2010.

[35] O. Malm, F. J. P. Branches, H. Akagi et al., "Mercury and methylmercury in fish and human hair from the Tapajos river basin, Brazil," Science of the Total Environment, vol. 175, no. 2, pp. 141-150, 1995.

[36] P. Grandjean, R. F. White, A. Nielsen, D. Cleary, and E. C. De Oliveira Santos, "Methylmercury neurotoxicity in Amazonian children downstream from gold mining," Environmental Health Perspectives, vol. 107, no. 7, pp. 587-591, 1999.

[37] C. J. S. Passos and D. Mergler, "Human mercury exposure and adverse health effects in the Amazon: a review," Cadernos de Saude Publica, vol. 24, no. 4, pp. S503-S520, 2008. 

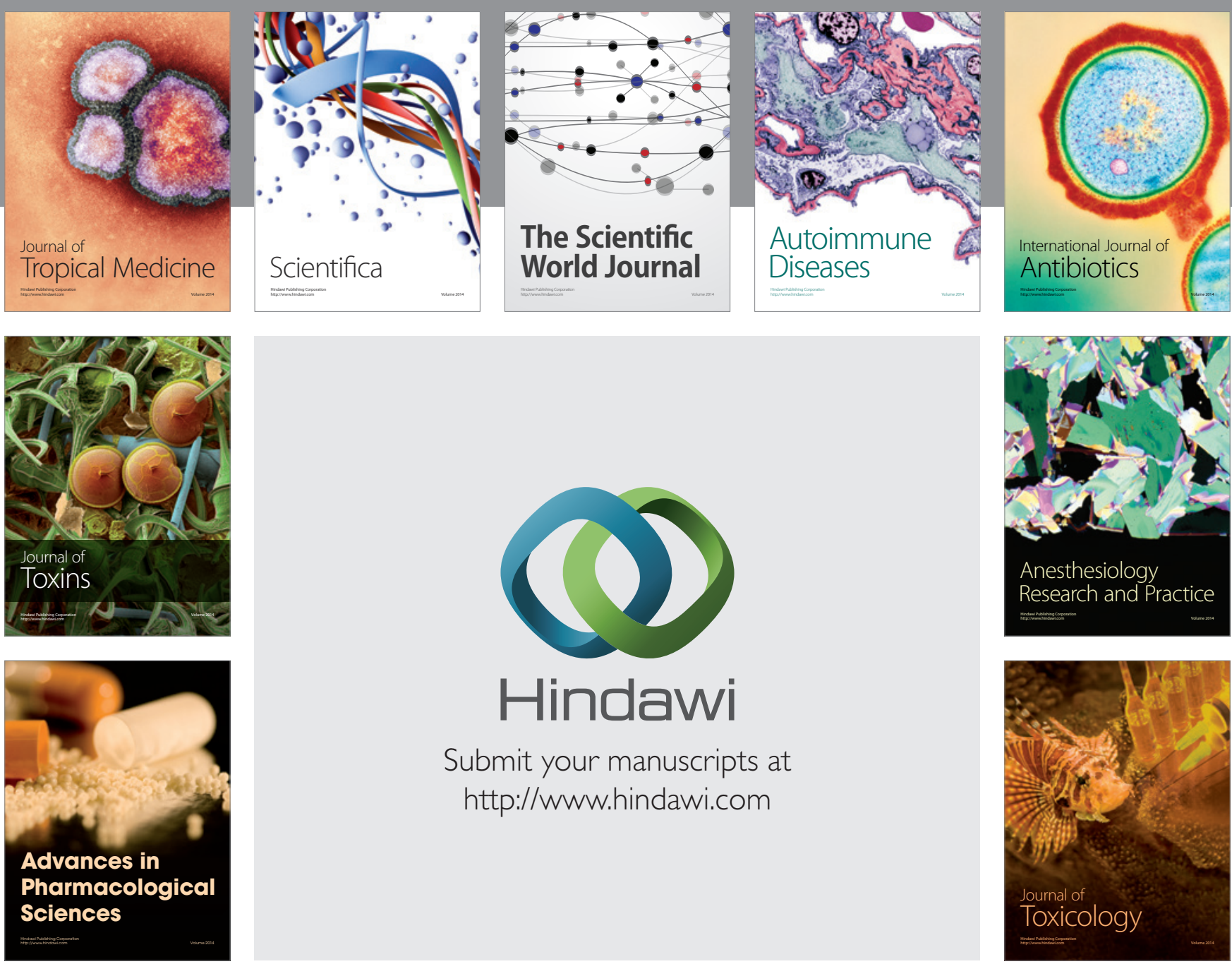

\section{Hindawi}

Submit your manuscripts at

http://www.hindawi.com
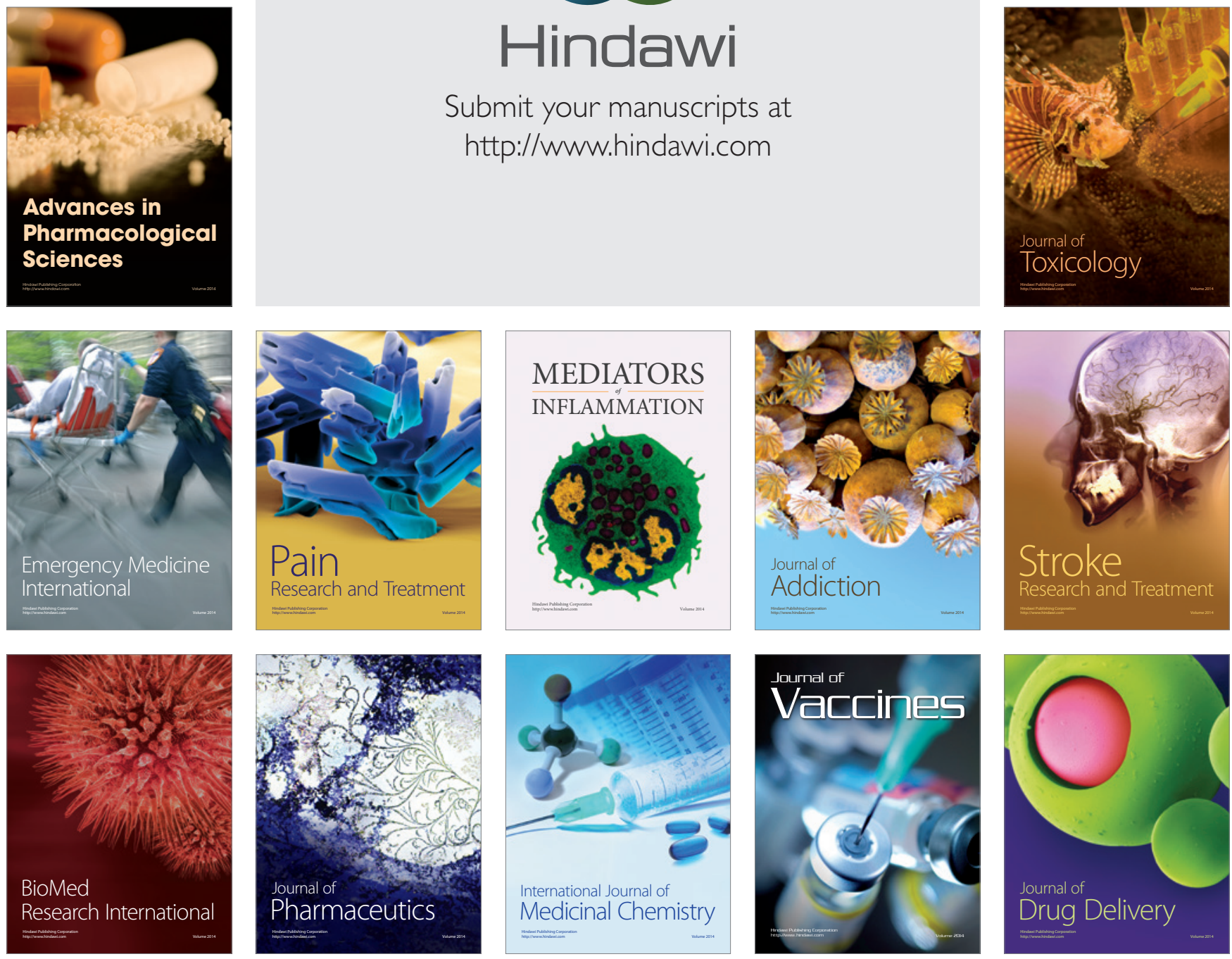